\title{
Analisis pendapatan usaha industri kerupuk amplang di Kecamatan Tungkal Ilir Kabupaten Tanjung Jabung Barat
}

\author{
Salman Alfarisyi*; Siti Hodijah; Nurhayani
}

\author{
Prodi Ekonomi Pembangunan, Fak. Ekonomi dan Bisnis, Universitas Jambi \\ *E-mail korespondensi: salmanalfarisyi95@gmail.com
}

\begin{abstract}
This study aims to analyze the socio-economic characteristics of entrepreneurs and the amplang cracker industry business, the magnitude of the amplang cracker industry business income, and the factors that affect the income of the amplang cracker industry entrepreneur in Tungkal Ilir District, Tanjung Jabung Barat Regency. The research method used in this study is a survey method, with descriptive analysis and quantitative analysis. Based on the results of data processing using the OLS method in multiple linear regression equations, the results obtained are: The socio-economic characteristics of all amplang cracker industry entrepreneurs are 83.33 percent with a high school graduatelequivalent. The average number of dependents and the number of workers is 4 people. The average net income of Rp. 15,753,334,- per month. Simultaneously, the variables of production costs, the amount of production, and the workforce have a significant effect on the business income of the amplang cracker industry. Partially shows that production costs, and the amount of production have a positive and significant effect on the business income of amplang crackers. Meanwhile, labor has no significant effect on the business income of the amplang cracker industry.
\end{abstract}

Keywords: Production, Labor, Revenue of amplang crackers industry

\begin{abstract}
Abstrak
Penelitian ini bertujuan untuk menganalisis karakteristik sosial ekonomi pengusaha dan usaha industri kerupuk amplang, besarnya pendapatan usaha industri kerupuk amplang dan faktor yang mempengaruhi pendapatan pengusaha industri kerupuk amplang di Kecamatan Tungkal Ilir Kabupaten Tanjung Jabung Barat. Metode penelitian yang digunakan pada penelitian ini adalah metode survey, dengan analisis deskriptif dan analisis kuantitatif. Berdasarkan hasil pengolahan data menggunakan metode OLS dalam persamaan regresi linear berganda diperoleh hasil: Karakteristik sosial ekonomi seluruh pengusaha industri kerupuk amplang adalah 83,33 persen berpendidikan tamatan SLTA/Sederajat. Rata-rata tanggungan dan jumlah tenaga kerjanya 4 orang. Rata-rata pendapatan bersih sebesar Rp. 15.753.334,-per bulannya. Secara simultan variabel biaya produksi, jumlah produksi dan teanga kerja berpengaruh signifikan terhadap pendapatan usaha industri kerupuk amplang. Secara parsial menunjukkan bahwa biaya produksi, dan jumlah produksi berpengaruh positif dan signifikan terhadap pendapatan usaha kerupuk amplang. Sedangkan tenaga kerja tidak berpengaruh signifikan terhadap pendapatan usaha industri kerupuk amplang.
\end{abstract}

Kata kunci : Produksi, Tenaga kerja, Pendapatan industri kerupuk amplang.

\section{PENDAHULUAN}

Industri adalah kegiatan ekonomi yang mengolah bahan mentah, bahan baku, barang setengah jadi atau barang jadi menjadi barang yang bermutu tinggi dalam penggunaannya, termasuk kegiatan merancang, membangun dan perekayasaan industri 
(Undang-undang Nomor 5 Tahun 1984 Pasal 1). Kartasapoetra (2000) menyatakan bahwa industri adalah kegiatan ekonomi yang mengolah bahan mentah, bahan baku, barang setengah jadi dan/atau barang jadi menjadi barang dengan nilai yang lebih tinggi lagi penggunaannya, termasuk kegiatan rancang bangun industri dan perekayasaan industri. Dengan demikian, industri merupakan bagian dari proses produksi. Bahanbahan industri diambil secara langsung maupun tidak langsung, kemudian diolah, sehingga menghasilkan barang yang bernilai lebih bagi masyarakat.

Perkembangan industri di Indonesia sekarang ini berlangsung sangat pesat seiring kemajuan ilmu pengetahuan dan teknologi. Proses industrialisasi masyarakat Indonesia semakin cepat di dukung juga dengan berdirinya perusahaan dan tempat kerja yang beraneka ragam.Dalam perkembangan yang di alami tidak hanya terjadi peningkatan, tetapi juga terjadi penurunan pada perindustrian itu sendiri. Sehingga dari tahun ke tahun perindustrian di Indonesia cenderung tidak stabil. Baik dari sektor pertanian, kerajinan tangan, makanan, properti, dan lain sebagainya setiap tahun mengalami peningkatan dan penurunan. Seperti industri kelapa sawit yang sedang mengalami penurunan. Dan saat ini banyak bermunculan industri-industri kecil di indonesia yang bertujuan untuk menopang perekonomian keluarga yang semakin memburuk. Peran industri kecil terhadap roda perekonomian suatu negara sangat besar. Amerika serikat misalnya, dari 5,5 juta usaha yang telah berjalan mantap, 95\% diantaranya merupakan usaha kecil. Kondisi serupa juga ditemukan di negara-negara maju lainnya, misalnya Jepang. Di Indonesia , 99\% dari total unit usaha yang mandiri (sekitar 35 juta) juga berupa unit usaha kecil. Hanya saja , kontribusi terhadap produk domestik bruto (PDB) baru 14\% saja. Hal ini menjadi tantangan bagi para pengusaha kecil untuk meningkatkan usahanya (Sarwono \& Saragih dalam Santoso dan Dumasari 2009). Kabupaten Tanjung Jabung Barat juga merupakan satu dari dua Kabupaten di Provinsi Jambi yang memiliki wilayah laut. Hal ini menyebabkan sebagian besar masyarakat tinggal dan menepati daerah sekitar wilayah pesisir serta menggantungkan hidupnya sebagai nelayan (Ningsih dalam Nurhayani dan Siti Hodijah, 2018).

Menurut Hasibuan (dalam Teguh, 2013) industri merupakan kumpulan perusahaanperusahaan yang menghasilkan barang-barang homogen, atau barang-barang yang mempunyai sifat saling mengganti yang sangat erat.

Kuncoro (2007) menyatakan industri dalam arti sempit adalah kumpulan perusahaan yang menghasilkan produk sejenis, dimana terdapat kesamaan dalam bahan baku yang digunakan, proses, bentuk produk akhir, dan konsumen akhir. Dalam arti yang lebih luas industri dapat didefinisikan sebagai kumpulan perusahaan yang memproduksi barang dan jasa dengan elastisitas silang (cross elastisities of demand) yang positif dan tinggi. Secara garis besar, industri dapat didefinisikan sebagai kelompok perusahaan yang memproduksi barang atau jasa yang sama atau bersifat substitusi.

Salah satu dari industri kecilnya seperti industri pembuatan kerupuk amplang yang berada di Kecamatan Tungkal Ilir Kabupaten Tanjung Jabung Barat. Dengan banyaknya aneka hasil laut yang ditemui di Kecamatan Tungkal Ilir Kabupaten Tanjung Jabung Barat, yang merupakan tempat berlabuhnya kapal nelayan dan sekaligus tempat perdagangan. Untuk itu pengembangan industri produk olahan ikan khususnya kerupuk Amplang memiliki potensi terhadapupaya pemberdayaan bagi peningkatan perekonomian masyarakat pesisir dan sekitarnya. Jumlah industri di Kabupaten Tanjung Jabung Barat pada tahun 2014 adalah 1.307 industri dan pada tahun 2015 jumlah industri di Kabupaten Tanjung Jabung Barat mengalami peningkatan menjadi 1.320 industri. Demikian pula dengan jumlah tenaga kerja pada tahun 2014 sebanyak 3.631 jiwa/orang. Dan pada tahun 2015 juga mengalami peningkatan menjadi 3.659 jiwa/orang. 
Secara logika jika suatu industri terus meningkat maka akan meningkatkan jumlah pendapatan pengusaha, jumlah produksi dan penyerapan tenaga kerja. Ini dikarenakan setiap idustri membutuhkan tenaga kerja dalam melakukan kegiatan industri, maka tenaga kerja akan terserap dan pengangguran akan berkurang. Jika tenaga kerja tersebut bekerja dengan maksimal serta efisien maka akan meningkatkan jumlah produksi, dan pendapatan usaha sehingga industri atau perusahaan akan berkembang/mengalami peningkatan. Begitu pula dengan usaha industri kerupuk amplang, yang terdapat di Kecamatan Tungkal Ilir Kabupaten Tanjung Jabung Barat, yang diharapkan dapat meningkatkan pengenalan kerupuk amplang kepada seluruh kalangan atau lapisan masyarakat dan dapat berkembang seperti industri-industri kerupuk yang sudah di kenal luas, akan tetapi faktanya industri ini masih belum dikenal dengan luas dikalangan masyarakat. Jika suatu industri terus berkembang maka akan meningkatkan jumlah pendapatan pengusaha, jumlah produksi dan penyerapan tenaga kerja.

\section{METODE}

\section{Jenis dan sumber data}

Data yang digunakan dalam penelitian ini adalah data primer dan data sekunder. Menurut Supranto (1993), data primer adalah data yang dikumpulkan langsung dari obyeknya dan diolah suatu organisasi atau perorangan. Data primer yang dikumpulkan dengan cara survei yaitu menanyakan langsung kepada pengusaha industri kerupuk amplang dengan menggunakan kuisioner dan interview kepada pihak-pihak yang berkaitan dengan penelitian ini. Sedangkan data sekunder adalah data yang diperoleh suatu organisasi atau perusahaan dalam bentuk yang sudah jadi berupa publikasi. Data sekunder dikumpulkan dari publikasi dengan mempelajari buku-buku, literatur, jurnal penelitian, artikel, sumber-sumber serta laporan-laporan yang ada hubungannya dengan penelitian ini.

\section{Sumber data}

Data adalah catatan atas kumpulan fakta, dalam penggunaan sehari-hari data berarti suatu pernyataan yang diterima secara apa adanya. Pernyataan ini adalah hasil pengukuran atau pengamatan suatu variabel yang bentuknya dapat berupa angka, katakata atau citra. Sumber data dalam penelitian adalah subjek dari mana data itu diperoleh. Adapun sumber data dalam penelitian ini terdiri dari data survei yang diperoleh dengan cara menunjukan kuisioner kepada pengusaha industri kerupuk amplang. Penelitian survei adalah penyelidikan yang dilakukan untuk mendapatkan fakta-fakta dari gejala yang ada dan mencari keterangan-keterangan secara faktual baik tentang institusi sosial, ekonomi atau politik dari suatu kelompok atau suatu individu (Moh. Nazir 2005). Kemudian data dari kantor dinas perindustrian dan perdagangan (DISPERINDAG) Kabupaten Tanjung Jabung Barat dan data dari badan pusat statistik (BPS) Propinsi Jambi.

\section{Populasi}

Adapun yang menjadi populasi dalam penelitian ini adalah seluruh pengusaha industri kerupuk amplang di Kecamatan Tungkal Ilir Kabupaten Tanjung Jabung Barat yang masih aktif yaitu sebanyak 30 industri. Husaini Usman (2006) mengemukakan populasi ialah semua nilai baik hasil perhitungan maupun pengukuran, baik kuantitatif maupun kualitatif, dari karakteristik tertentu mengenai sekelompok objek yang lengkap dan jelas.

Menurut Sugiyono (2006), Populasi adalah wilayah generalisasi yang terdiri atas objek/subjek yang mempunyai kualitas dan karakteristik tertentu yang ditetapkan oleh 
peneliti untuk dipelajari dan kemudian ditarik kesimpulannya. Menurut Arikunto (2010), jika populasi atau subjeknya kurang dari 100 maka dipakai rumus $\mathrm{N}=\mathrm{n}$ yang artinya semua populasi adalah sampel dan jika populasi atau subjeknya besar dari 100 dapat di ambil $10-15 \%$ atau $20-25 \%$ atau lebih. Dari populasi industri kerupuk amplang yang ada, paling banyak terdapat pada kawasan Jalan Kalimantan, adapun sampel yang di ambil untuk di teliti dalam penelitian ini adalah semua populasi industri kerupuk amplang di Kecamatan Tungkal Ilir Kabupaten Tanjung Jabung Barat.

\section{Analisis data}

Analisis yang digunakan yaitu analisis deskriptif dan analisis kuantitatif. Analisis deskriptif dilakukan bertujuaan untuk menjawab rumusan masalah pertama yaitu untuk mempresentasikan kondisi sosial ekonomi serta pengamatan terkait dengan data penunjang lainnya berdasarkan laporan dan menganalisis data yang tidak berbentuk angka, tetapi dalam bentuk pertanyaan-pertanyaan, kondisi, situasi dan lain-lain yang akan di gambarkan dengan kata-kata. Dan analisis kuantitatif dalam bentuk informasi data dan tabel dengan menggunakan data dari Dinas Perindustrian dan Perdagangan (DISPERINDAG) dan Badan Pusat Statistik (BPS). Untuk mengetahui besar pendapatan, biaya produksi, jumlah produksi dan jumlah tenaga kerja dari usaha industri kerupuk amplang di Kecamatan Tungkal Ilir Kabupaten Tanjung Jabung Barat.

Alat analisis yang digunakan adalah model regresi berganda. Secara umum hubungan antara variabel biaya produksi, jumlah produksi dan tenaga kerja (variabel independen) dan pendapatan industri (vaariabel dependen) tersebut dapat dituliskan dengan persamaan Cobb Douglass yaitu sebagai berikut:

$Q=\alpha X 1^{b 1} X 2^{b 2}$

Selanjutnya bentuk atau model umum ini diubah menjadi hubungan yang bersifat linear, maka ditransformasikan dalam bentuk logaritma, dengan formula sebagai berikut:

\section{$\log Y=\log \beta_{0}+\beta_{1} \log X_{1}+\beta_{2} \log X_{2}+\beta_{3} \log X_{3}+e$}

\section{Dimana:}

Y $\quad=$ Pendapatan usaha kerupuk amplang

$\beta_{0}, \beta_{1}, \beta_{2}, \beta_{3}=$ Konstanta

$\mathrm{X} 1=$ Biaya produksi

$\mathrm{X} 2=$ Jumlah produksi

X3 $=$ Tenaga kerja

$\mathrm{e} \quad=$ Error term

\section{Pengujian hipotesis}

\section{Pengujian hipotesis secara simultan (Uji F statistik)}

Untuk menguji hipotesis secara simultan yaitu pengaruh variabel biaya produksi, jumlah produksi dan tenaga kerja terhadap pendapatan industri kerupuk amplang dilakukan dengan menggunakan uji $\mathrm{F}$ atau $\mathrm{F}$ test. Uji $\mathrm{F}$ ini dilakukan dengan membandingkan antara $\mathrm{F}$ hitung dengan $\mathrm{F}$ tabel pada taraf signifikansi $(\alpha)$ tertentu. Uji $\mathrm{F}$ ini dilakukan dengan menggunakan rumus berikut.

$$
\mathbf{F}_{\text {rasio }}=\frac{R^{2} / k-1}{\left(1-R^{2}\right) /(N-k)}
$$


Keterangan :

$\mathrm{R}^{2}=$ Koefisien determinasi

$\mathrm{K}$ = Jumlah variabel bebas

$\mathrm{N}$ = Jumlah observasi

Jika $\mathrm{F}$ rasio $>\mathrm{F}$ tabel dengan taraf nyata $(\alpha)$ tertentu, maka pengaruh variabelvariabel bebas (biaya produksi, jumlah produksi dan tenaga kerja) secara bersama-sama terhadap variabel terikat (pendapatan industri kerupuk amplang) adalah signifikan dan jika $F$ rasio $<F$ tabel dengan taraf nyata $(\alpha)$ tertentu, maka pengaruh variabel-variabel bebas (biaya produksi, jumlah produksi dan tenaga kerja) secara bersama-sama terhadap variabel terikat (pendapatan industri kerupuk amplang) adalah tidak signifikan.

\section{Pengujian hipotesis secara parsial (Uji t )}

Untuk menguji hipotesis secara parsial yaitu pengaruh variabel biaya produksi, jumlah produksi dan tenaga kerja terhadap pendapatan industri kerupuk amplang dilakukan dengan menggunakan uji $t$ atau $t$ tes.

Uji $t$ ini dilakukan dengan membandingkan antara $t$ hitung dengan $t$ tabel pada taraf signifikansi $(\alpha)$ tertentu. Uji t ini dilakukan dengan menggunakan rumus berikut.

Keterangan :

$$
\text { thitung }=\frac{b i}{\operatorname{Se}(b i)}
$$

bi $\quad=$ Koefisien regresi variabel bebas sektor ke $\mathrm{i}$

$\mathrm{Se}(\mathrm{bi})=$ Standar error dari koefisien regresi bi

Jika nilai $\mathrm{t}_{\text {hitung }}>\mathrm{t}_{\text {tabel }}$ atau nilai probabilitasnya kecil dari nilai $(\alpha)$ maka variabelvariabel (biaya produksi, jumlah produksi dan tenaga kerja) secara parsial atau individu mempunyai pengaruh yang signifikan terhadap variabel terikat (pendapatan industri kerupuk amplang). Dan jika nilai $\mathrm{t}_{\text {hitung }}<\mathrm{t}_{\text {tabel }}$ atau nilai probabilitasnya besar dari nilai ( $\alpha$ ) maka variabel-variabel bebas (biaya produksi, jumlah produksi dan tenaga kerja) secara parsial atau individu mempunyai pengruh yang tidak siknifikan terhadap variabel terikat (pendapatan industri kerupuk amplang).

\section{Uji koefisien determinasi $\left(\mathbf{R}^{2}\right)$}

Koefisien Determinasi $\left(\mathrm{R}^{2}\right)$, merupakan ukuran untuk mengetahui kemampuan variabel bebas , menjelaskan variabel tidak bebas yang dirumuskan dengan:

$$
R^{2}=\frac{1-\sum e i}{\sum e^{2}}
$$

Nilai $\mathrm{R}^{2}$ berkisar antara 0 dan 1 , nilainya mendekati 1 berarti sumbangan variabel $\mathrm{X}$ semakin menentukan $\mathrm{Y}$, jika 0 berarti sumbangan variabel $\mathrm{X}$ terhadap variabel $\mathrm{Y}$ semakin kecil.

\section{Uji asumsi klasik}

\section{Uji multikolinieritas}

Multikolinearitas adalah adanya hubungan (sempurna atau tidak sempurnanya) diantara beberapa atau semua variabel independen dalam model regresi. Jika multikolinearitas sempurna maka besaran koefisien regresi tidak dapat ditentukan. Jika multikolinearitas tidak sempurna maka koefisien regresi tidak memiliki ketepatan yang tinggi. 
Sebuah model yang mengandung multikolinearitas dapat ditunjukkan oleh indikasi sebagai berikut: apabila $R^{2}$ tinggi, tetapi sedikit sekali t-statistik yang signifikan dan adanya korelasi yang tinggi antara variabel independen.

\section{Uji normalitas}

Uji normalitas bertujuan untuk melihat apakah residualnya terdistribusi secara normal atau tidak sesuai dengan asumsi model regresi yang Best Linier Unbias Estimator (BLUE) dari klasik adalah dengan membandingkan nilai Jarque-Berra dengan Chi-square $X^{2}$. Jika nilai Jarque-Berra lebih kecil dari nilai tanel chi-square $\left(X^{2} i\right.$, maka dikatakan model lolos dari ketidak normalan distribusi residualnya.

\section{Uji autokorelasi}

Autokorelasi adalah suatu hubungan antara residual satu observasi dengan residual observasi lainnya. Autokorelasi mudah muncul pada data yang bersifat runtut waktu, karena berdasarkan sifatnya data di masa sekarang dipengaruhi oleh data-data masa sebelumnya. Cara untuk memeriksa ada tidaknya autokoreasi adalah dengan melakukan uji Durbin-Watson (DW) dengan ketentuan: Jika $\mathrm{d}<\mathrm{dL}$ maka hipotesis nol ditolak yang berarti di putuskan terdapat autokorelasi, jika d $>4$-dL, maka hipotesis nol ditolak yang berarti terdapat autokorelsi, jika du $<\mathrm{d}<4$-du, maka hipotesis nol diterima berarti tidak terdapat autokorelasi dan jika $\mathrm{dL} \leq \mathrm{d} \leq \mathrm{du}$ atau 4 -du $\leq \mathrm{d} \leq 4$-dL, maka berarti hasil kesimpulan tidak pasti.

\section{Uji heterokedastisitas}

Uji heterokedastisitas dilakukan untuk menguji apakah dalam sebuah model regresi terjadi ketidak samaan varians dari residual pengamatan satu ke residual ke pengamatan lain tetap, maka telah terjadi heterokedastisitas. Regresi yang baik adalah yang tidak terjadi heterokedasttisitas.

Heterokedastisitas terjadi bila variabel gangguan mempunyai variabel yang sama untuk mendeteksi ada atau tidaknya heterokedastisitasnya digunakan uji Glejser heteroskedasticity test. Jika nilai Chi-square tabel $\left(\mathrm{X}^{2}<\alpha=0,05\right.$ maka terjadi gejala heterokedasitisitas namun apabila nilai Chi square tabel $\left(\mathrm{X}^{2}\right)>\alpha=0,05$ berarti tidak terjadi heterokedastisitas.

\section{HASIL DAN PEMBAHASAN}

Analisis data dan pengujian dalam penelitian ini dilakukan dengan menggunakan model regresi linear berganda, dimana dalam analisis regresi linear berganda tersebut menguji seberapa pengaruh biaya produksi, jumlah produksi, dan tenaga kerja terhadap pendapatan usaha industri kerupuk amplang. Untuk memperkecil variasi data yang diperoleh maka data-data tersebut ditransformasikan ke dalam bentuk logaritma (Log). Berikut hasil analisis regresi berganda dapat di lihat pada Tabel 1 dibawah:

Tabel 1. Hasil analisis regresi berganda

\begin{tabular}{ccccc}
\hline Variable & Coefficient & Std. Error & t-Statistic & Prob. \\
\hline C & 4.697088 & 0.090683 & 51.79682 & 0.0000 \\
LOGX1 & 1.013802 & 0.011854 & 85.52076 & 0.0000 \\
LOGX2 & 0.030274 & 0.012753 & 2.373859 & 0.0253 \\
LOGX3 & -0.003643 & 0.011550 & -0.315388 & 0.7550 \\
\hline R-squared & 0.999198 & & & \\
Adjusted R-squared & 0.999105 & Durbin-Watson stat & 1.771472 \\
F-statistic & 10793.66 & & & \\
Prob(F-statistic) & 0.000000 & & & \\
\hline
\end{tabular}

Sumber: Data Diolah, 2019 
Berdasarkan Tabel 1 dapat dibuat persamaan sebagai berikut :

$$
\begin{aligned}
& \mathrm{Y}=4.697088+1.013802 \log \mathrm{X}_{1}+0.030274 \log \mathrm{X}_{2}-0.003643 \log \mathrm{X}_{3}+\mathrm{e} \\
& \begin{array}{llll}
(0.0000) & (0.0000) & (0.0253) & (0.7550)
\end{array}
\end{aligned}
$$

Angka dalam kurung merupakan nilai probabilitas $t_{\text {hitung }}$

$$
\begin{array}{ll}
\mathrm{R}^{2} & =0.999198 \\
\mathrm{R}_{\text {adjust }} & =0.999105 \\
\mathrm{~F}_{\text {hitung }} & =10793.66
\end{array}
$$

Nilai koefisien biaya produksi (X1) sebesar 1.013802 dengan probabilitas nya yang kecil dari pada nilai $\alpha=0,05$, maka dinyatakan berpengaruh signifikan terhadap pendapatan (Y). Hal ini menunjukkan bahwa biaya produksi berpengaruh terhadap pendapatan usaha kerupuk amplang dengan asumsi X2 dan X3 konstan, nilai koefisien jumlah produksi (X2) sebesar 0.030274 dengan probabilitas kecil dari pada nilai $\alpha=$ 0,05 maka dinyatakan berpengaruh signifikan terhadap pendapatan (Y). Hal ini menunjukkan bahwa semakin tinggi jumlah produksi maka akan semakin tinggi juga pendapatan usaha kerupuk amplang dengan asumsi X1 dan X3 konstan, dan nilai koefisien tenaga kerja (TK) sebesar -0.003643, dengan probabilitas lebih besar dari pada niai $\alpha=0,05$ maka dinyatakan tidak berpengaruh signifikan terhadap pendapatan (Y). Hal ini menunjukkan bahwa semakin banyak tenaga kerja dalam produksi akan mengurangi pendapatan usaha kerupuk amplang, dengan asumsi X1 dan X2 konstan.

\section{Uji hipotesis secara simultan (Uji F)}

Uji F digunakan untuk mengetahui apakah variabel-variabel independent berpengaruh signifikan terhadap variabel dependent. Derajat kepercayaan yang digunakan adalah 0,05. Pengujian ini dilakukan dengan membandingkan nilai $F_{\text {hitung }}$ dengan nilai $F_{\text {tabel }}$, apabila nilai $F_{\text {hitung }}$ lebih besar dari nilai $F_{\text {tabel }}$ atau nilai Prob(Fstatistic) $<$ nilai $(\alpha)=0,05$, maka hipotesis alternatif yang menyatakan bahwa semua variabel independent secara simultan berpengaruh signifikan terhadap veriabel dependent. Berdasarkan perhitungan statistik dengan bantuan Eviews diperoleh nilai $F_{\text {hitung }}$ sebesar (10793.66) dan nilai $F_{\text {tabel }}$ sebesar $(2,98)$.

Dengan demikian dapat dinyataan bahwa $F_{\text {hitung }}(10793.66)>F_{\text {tabel }}(2,98)$, atau nilai Prob $(\mathrm{F}$-statistic $)=0.000000<$ nilai $(\alpha)=0,05$, yang berarti $\mathrm{H}_{0}$ ditolak dengan artian bahwa ada pengaruh (signifikan). Hal ini menunjukkan bahwa secara bersamasama biaya produksi, jumlah produksi dan tenaga kerja berpengaruh nyata atau signifikan terhadap pendapatan usaha kerupuk amplang.

\section{Uji hipotesis secara parsial (Uji t)}

Pengujian secara parsial atau uji t dimaksudkan untuk mengetahui apakah variabel-variabel independent secara individual atau sendiri-sendiri berpengaruh nyata atau tidak terhadap variabel dependent. Dengan derajat signifikansi yang digunakan adalah 0,05. Apabila nilai signifikansi lebih kecil dari pada derajat kepercayaan maka kita menerima hipotesi alternatif yang menyatakan bahwa suatu variabel independent secara parsial mempengaruhi variabel dependent. Pada penelitian ini digunakan uji 2 arah dengan tingkat ke percayaan $95 \%(\mathrm{a}=5 \%$ atau 0,05$)$ serta derajat kebebasan $(\mathrm{df})$, maka diperoleh nilai $t_{\text {tabel }}=2,055$. Berikut ini dijelaskan pengujian hipotesis dari masing-masing variabel bebas (variabel independent) tersebut.

\section{Biaya produksi (X1)}

Secara statistik melalui hasil analisis hasil perhitungan terhadap $t_{\text {hitung }}$ untuk koefisien biaya produksi diketahui sebesar (85.520) sementara $t_{\text {tabel }}(2,055)$ atau niai 
probabilitasnya kecil dari nilai $\alpha=0,05$ yaitu 0.0000 . Dengan demikian dapat dinyatakan bahwa $t_{\text {hitung }}(85.520)>t_{\text {tabel }}(2,055)$ maka $\mathrm{H}_{0}$ ditolak yang artinya biaya produksi berpengaruh signifikan terhadap pendapatan usaha industri kerupuk amplang.

\section{Jumlah produksi (X2)}

Secara statistik melalui hasil analisis hasil perhitungan terhadap $\mathrm{t}_{\text {hitung }}$ untuk koefisien jumlah produksi diketahui sebesar (2.373) sementara $t_{\text {tabel }}(2,055)$ atau niai probabilitasnya kecil dari nilai $\alpha=0,05$ yaitu 0.0000. Dengan demikian dapat dinyatakan bahwa $t_{\text {hitung }}(2.373)>\mathrm{t}_{\text {tabel }}(2,055)$ maka $\mathrm{H}_{0}$ ditolak artinya jumlah produksi berpengaruh signifikan terhadap pendapatan usaha kerupuk amplang.

\section{Tenaga kerja (X3)}

Secara statistik melalui hasil analisis perhitungan terhadap $t_{\text {hitung }}$ untuk koefisien tenaga kerja diketahui sebesar $(-0.315)$ sementara $t_{\text {tabel }}(2,055)$ atau niai probabilitasnya lebih besar dari nilai $\alpha=0,05$ yaitu 0.7550 . Dengan demikian dapat dinyatakan bahwa $t_{\text {hitung }}(-0.315)<t_{\text {tabel }}(2,055)$ maka $\mathrm{H}_{0}$ diterima yang artinya tenaga kerja tidak berpengaruh signifikan terhadap pendapatan usaha kerupuk amplang.

\section{Koefisien determinasi $\left(\mathbf{R}^{2}\right)$}

Berdasarkan pengaruh variabel independen (biaya produksi, jumlah produksi dan tenaga kerja) terhadap variabel dependen (pendapatan usaha) dapat dilihat dengan nilai koefisien determinasi. Uji koefisien determinasi dimaksudkan untuk menguji kecocokan dan ketepatan model. Secara statistik jika nilai koefisien determinasi $\left(R^{2}\right)$ semakin mendekati 1 (satu) maka dapat diartikan bahwa koefisien determinasi $\left(\mathrm{R}^{2}\right)$ nilainya semakin tepat menaksir garis linear tersebut.

Dari hasil pengolahan data diperoleh nilai koefisien determinasi $\left(\mathrm{R}^{2}\right)$ sebesar 0,999 . Artinya variasi perubahan variabel pendapatan usaha industri kerupuk amplang di Kecamatan Tungkal Ilir Kabupaten Tanjung Jabung Barat mampu dijelaskan oleh variasi perubahan variabel biaya produksi, jumlah produksi dan tenaga kerja sebesar 99,9 persen. Sedangkan sisanya sebesar 0,01 persen dijelaskan oleh variabel lain diluar model.

\section{Uji asumsi klasik}

\section{Uji multikolinearitas}

Multikolinearitas adalah hubungan yang terjadi diantara variabel-variabel independen yang lain. Pengujian terhadap gejala multikolinearitas dapat dilakukan dengan melihat besarnya koefisien determinasi parsial $\left(\mathrm{R}^{2}\right)$, jika $\mathrm{R}^{2}$ lebih kecil dari $10 \%$ maka tidak ada multikolinearitas dan sebaliknya jika $\mathrm{R}^{2}$ lebih besar dari $10 \%$ maka ada terjadi multikolinearitas.

Tabel 2. Hasil uji multikolinearitas

\begin{tabular}{cccc}
\hline Variabel & LOGX1 & LOGX2 & LOGX3 \\
\hline LOGX1 & 1.000000 & -0.884936 & -0.817594 \\
LOGX2 & -0.884936 & 1.000000 & 0.893453 \\
LOGX3 & -0.817594 & 0.893453 & 1.000000 \\
\hline
\end{tabular}

Sumber : Data diolah, 2019 
Dari Tabel 2 dapat dilihat bahwa tidak terdapat variabel yang memiliki nilai lebih dari 1 sehingga dapat disimpulkan bahwa tidak terjadi multikolinearitas dalam model regresi.

\section{Uji normalitas}

Uji normalitas adalah pengujian yang dilakukan untuk mengetahui apakah model regresi dalam penelitian nilai residualnya berdistribusi sercara normal atau tidak. Dasar pengambilan keputusan dalam mendeteksi normalitas yaitu dengan membandingkan nilai Jarque-Bera dengan nilai $\mathrm{X}^{2}$ tabel dan keputusanya yaitu apabila nilai Jarque-Berra $>$ nilai $\mathrm{X}^{2}$ tabel (dengan $\alpha=5 \%$ ) atau probabilitasnya $<0,05$ maka dapat disimpulkan bahwa data yang digunakan tidak berdistribusi normal dan sebaliknya, jika nilai JarqueBerra $<$ nilai $X^{2}$ tabel atau probabilitasnya > 0,05 maka dapat disimpulkan bahwa data yang digunakan berdistribusi normal. Berikut adalah hasil uji normalitas yang dapat dilihat pada Gambar 1. dibawah :

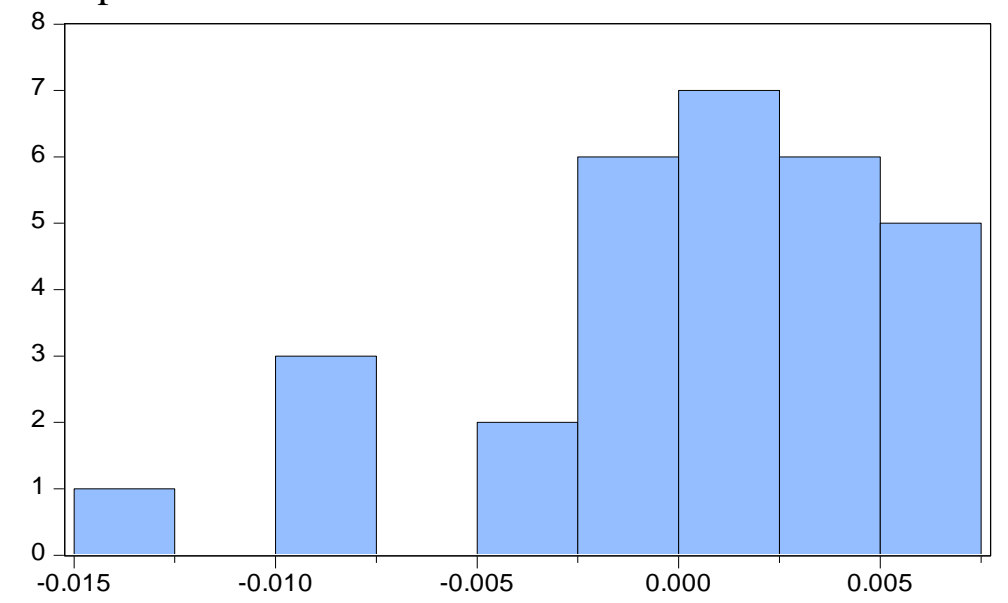

\begin{tabular}{|lr|}
\hline \multicolumn{2}{|l|}{ Series: Residuals } \\
Sample 1 30 \\
Observations 30 \\
Mean & $5.27 \mathrm{e}-16$ \\
Median & 0.000142 \\
Maximum & 0.006707 \\
Minimum & -0.013078 \\
Std. Dev. & 0.004610 \\
Skewness & -0.924864 \\
Kurtosis & 3.782799 \\
& \\
Jarque-Bera & 5.042836 \\
Probability & 0.080346 \\
\hline
\end{tabular}

Gambar 1. Hasil uji normalitas

Berdasarkan Gambar 1 diatas dapat diketahui bahwa nilai nilai probability sebesar 0,08, maka sesuai ketentuan 0,08 >0,05 maka nilai residual tersebut adalah normal.

\section{Uji autokorelasi}

Autokorelasi adalah keadaan dimana faktor-faktor pengganggu yang satu dengan yang lain saling berhubungan. Pengujian terhadap gejala autokorelasi dalam penelitian ini dilakukan dengan menggunakan uji Durbin-Watson, yaitu berguna untuk mengetahui apakah model yang digunakan ada atau tidaknya gejala autokorelasi di antara variabel-variabel yang diamati.

Tabel 3. Hasil uji autokorelasi

\begin{tabular}{lclc}
\hline \hline R-squared & 0.068131 & Mean dependent var & $5.27 \mathrm{E}-16$ \\
Adjusted R-squared & -0.126008 & S.D. dependent var & 0.004610 \\
S.E. of regression & 0.004892 & Akaike info criterion & -7.625619 \\
Sum squared resid & 0.000574 & Schwarz criterion & -7.345380 \\
Log likelihood & 120.3843 & Hannan-Quinn criter. & -7.535968 \\
F-statistic & 0.350941 & Durbin-Watson stat & 1.905392 \\
Prob(F-statistic) & 0.876548 & & \\
\hline
\end{tabular}

Sumber : Data diolah, 2019 
Berdasarkan Tabel 3 dapat diketahui bahwa hasil uji autokorelasi dengan menggunakan Durbin-Watson maka dapat dilihat nilai Durbin-Watson stat 1,905392 dengan diketahui nilai dL $(1,1426)$, nilai du $(1,7386)$ maka du $(1,7386)<\mathrm{d}(1,905392)$ < 4-du (2,094608) sehingga berdasarkan uji hipotesis maka $\mathrm{H}_{0}$ diterima, dengan diterimanya $\mathrm{H}_{0}$, berarti tidak ditemukan adanya masalah gejala autokorelasi pada model empiris yang digunakan dalam penelitian ini, atau dinyatakan terbebas dari masalah autokorelasi.

\section{Uji heterokedastisitas}

Salah satu asumsi klasik yang menjadi bagian dalam prosedur uji disini adalah uji heteroskedastisitas. Heteroskedastisitas merupakan salah satu asumsi OLS jika varian residualnya tidak sama. Untuk mengetahui gejala heteroskedastisitas dalam penelitian ini dilakukan dengan Uji Glejser dalam program Eviews yaitu dengan Glejser heteroskedasticity Test. Keputusan ada tidaknya heteroskedastisitas ditentukan dengan

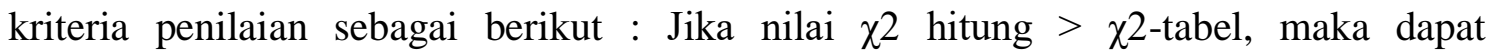
disimpulkan bahwa model empiris tidak terbebas dari masalah heteroskedastisitas dan jika nilai $\chi 2$-hitung $<\chi 2$-tabel, maka dapat disimpulkan bahwa model empiris bebas dari masalah heteroskedastisitas.

Tabel 4. Hasil uji heterokedastisitas

\begin{tabular}{llll}
\hline F-statistic & 1.861146 & Prob. F(3,26) & 0.1610 \\
Obs*R-squared & 5.303513 & Prob. Chi-Square(3) & 0.1509 \\
Scaled explained SS & 6.184401 & Prob. Chi-Square(3) & 0.1030 \\
\hline
\end{tabular}

Sumber : Data diolah, 2019

Dari Tabel 4 menunjukkan bahwa uji Glejser menghasilkan kesimpulan tidak ada masalah heterokedastisitas, hal ini dibuktikan dengan nilai Obs*R-squared 5.303513 dengan Prob 0.1509, yang mana lebih besar dari pada tingkat signifikansi 5\% $(\alpha=0,05)$ atau $0.1509>0,05$. Maka dari itu dapat disimpulkan bahwa tidak terdapat gejala heterokedastisitas.

\section{Pengaruh biaya produksi terhadap pendapatan}

Dari hasil estimasi regresi menjukkan bahwa variabel biaya produksi, dengan tingkat signifikansi $5 \%$ berpengaruh signifikan terhadap pendapatan usaha kerupuk amplang. Bertambahnya biaya produksi maka akan menyebabkan berkurangnya pendapatan. Besaran koefisien untuk variabel biaya produksi adalah 1.013, dengan demikian setiap terjadi peningkatan biaya produksi sebanyak 1 persen maka akan mempengaruhi pendapatan sebesar 1.013 persen.

\section{Pengaruh jumah produksi terhadap pendapatan}

Dari hasil estimasi regresi menunjukkan bahwa variabel jumlah produksi dengan tingkat signifikansi $5 \%$ berpengaruh positif dan signifikan terhadap pendapatan usaha kerupuk amplang. Dengan bertambahnya jumlah produksi maka akan meningkatkan pendapatan usaha kerupuk amplang. Besaran koefisien untuk variabel jumlah produksi adalah 0.030 , dengan demikian setiap terjadi peningkatan jumlah produksi sebanyak 1 persen maka akan meningkatkan pendapatan sebesar 0.030 persen. 


\section{Pengaruh tenaga kerja terhadap pendapatan}

Dari hasil estimasi regresi menunjukkan bahwa variabel tenaga kerja dengan tingkat signifikansi $5 \%$ atau $\alpha=0,05$ tidak berpengaruh signifikan terhadap pendaptan usaha kerupuk amplang. Karena tidak terlalu bergantung pada jumah tenaga kerja dalam produksinya dan dilihat juga dari besaran koefisien untuk variabel tenaga kerja adalah 0.003 , dengan nilai probabilitas sebesar 0.7549 yang mana lebih besar dari pada nilai alpha 0,05 , setiap terjadi peningkatan tenaga kerja maka akan mengurangi pendapatan usaha kerupuk amplang. dengan demikian setiap penambahan sebanyak 1 orang tenaga kerja maka pendapatan usaha industri kerupuk amplang hanya akan berkurang sebanyak -0.003 persen.

\section{KESIMPULAN DAN SARAN}

\section{Kesimpulan}

Karakteristik sosial ekonomi pengusaha industri kerupuk amplang di Kecamatan Tungkal Ilir Kabupaten Tanjung Jabung Barat adalah perempuan, rata-rata berumur 39 tahun, 83,33 persen berpendidikan SLTA/Sederajat dengan tanggungan 4 orang dan seluruhnya menjadikan usaha kerupuk amplang sebagai pekerjaan utamanya. Rata-rata tenaga kerjanya 4 orang, rata-rata jam kerja 194 jam, jumlah produksi rata-rata 299 kilogram perbulannya, dengan harga jual rata-rata Rp.82.000,-perkilogram. Biaya operasional sebagian besar responden sebesar Rp.6.85.000 per hari, 40 persen responden berpendapatan berkisar Rp.7.801.250 - Rp.11.777.291. Dengan rata-rata pendapatan bersih sebesar Rp. 15.753.334,--

Secara simultan menunjukkan bahwa variabel biaya produksi, jumlah produksi dan teanga kerja berpengaruh signifikan terhadap pendapatan usaha industri kerupuk amplang. Sedangkan secara parsial menunjukkan biaya produksi dan jumlah produksi berpengaruh signifikan terhadap pendapatan usaha kerupuk amplang, kemudian variabel tenaga kerja tidak berpengaruh signifikan terhadap pendapatan usaha industri kerupuk amplang.

\section{Saran}

Perlu adanya perhatian dari pemerintah dalam hal memantau, mengembangkan usaha ini perluasan pangsa pasar melalui acara promosi atau pameran produk-produk hasil industri makanan khas daerah agar dapat menjadi produk khas dan dikenal luas, serta melakukan pelatihan-pelatihan demi meningkatkan, keahlian dan kompetensi tenaga kerja. Sehingga diharapkan permintaan terhadap kerupuk amplang dapat meningkat, jumlah produksi meningkat dan pendapatan usahapun juga meningkat.

Dengan adanya peningkatan jumah produksi, diharapkan pengusaha kerupuk amplang dapat meningkatkan kualitas dan berinovasi dalam menghasilkan produk yang lebih baik serta meningkatkan jumlah pendapatan.

\section{DAFTAR PUSTAKA}

Arikunto, Suharsimi. (2010). Prosedur penelitian suatu pendekatan praktik. Rineka Cipta: Jakarta.

Husaini Usman; \& Purnomo Setiady Akbar. (2006). Pengantar statistika. Bumi Aksara: Jakarta. 
Kartasapoetra. G (2000). Pembentukan perusahaan industri. Grafindo Persada: Jakarta. Kuncoro, M. (2007). Ekonomika industri Indonesia. Andi: Yogyakarta.

Mulyadi, A; Hardiani,H; \& E Umiyati. (2018).Faktor-faktor yang mempengaruhi penyerapan tenaga kerja pada sektor industri kecil di Kabupaten Muaro Jambi, e-Jurnal Perdagangan Industri dan Moneter, 6 (1), 35-44

Nazir, Moh. (2005). Metode penelitian. Ghalia Indonesia: Jakarta.

Nurhayani; \& Siti Hodijah, (2018). Kemiskinan dan kondisi pemukiman nelayan tradisional (studi di Kelurahan Kampung Nelayan Kecamatan Tungkal Ilir Kabupaten Tanjung Jabung Barat). Jurnal Paradigma Ekonomika.13(2), 55-64.

Rahayu,W.P; Prihanto, P.H; \& Achmad, E. (2016). Faktor-faktor yang mempengaruhi penyerapan tenaga kerja pada industri batik di Kecamatan Danau Teluk Kota Jambi, e-Jurnal Ekonomi Sumberdaya dan Lingkungan, 5 (3)

Sugiyono. (2006). Metode penelitian kuantitatif kualitatif dan $R \& D$. Alfabeta: Bandung.

Supranto, Johannes. (1993). Metode ramalan kuantitatif untuk perencanaan ekonomi dan bisnis. Rineka Cipta: Jakarta.

Syahputra,YT; \& Parmadi,P. (2017).Faktor-faktor yang mempengaruhi pendapatan usaha pedagang ikan di pasar tradisional Kota Jambi, e-Jurnal Perspektif Ekonomi dan Pembangunan Daerah, 6 (3), 121-130

Teguh, Muhammad. (2013). Ekonomi industri . PT. RajaGrafindo Persada: Jakarta.

Utami, Santoso; \& Dumasari. (2009). Analisis pendapatan dan biaya produksi agroindustri tahu di Desa Pandansari Kecamatan Ajibarang Kabupaten Banyumas. Jurnal Agritech. 11(1), 45-55. 